\title{
KONSTRUKSI AJARAN BUDAYA PERGURUAN ILMU SEJATI DALAM RELASINYA DENGAN NILAI KEISLAMAN
}

\author{
Nurul Huda \\ Balai Penelitian dan Pengembangan Agama Semarang \\ nurulhuda050401@windowwslive.com
}

\begin{abstract}
Abstrak
Penelitian ini merupakan kajian analisis isi dengan pendekatan kualitatif. Tujuan penelitian ini adalah untuk mendeskripsikan konstruksi ajaran budaya penghayat kepercayaan ilmu sejati dalam relasinya dengan nilai keislaman. Pengumpulan data dilakukan dengan studi dokumen dan wawancara untuk memperoleh teks transkrip konfirmasi ajaran yang keduanya dianalisis dengan metode analisis isi. Hasil analisis menunjukkan bahwa substansi teoritik ajaran budaya Perguruan Ilmu Sejati adalah mengenai moral atau adat istiadat baik yang secara istilah merupakan terjemahan dari ajaran Tasawuf/Akhlak dalam Islam menurut pengetahuan individual Guru yang pertama kali memulai mengajarkan wirid. Substansi praktik ajaran budaya tersebut adalah wirid yang tidak dapat diketahui kecuali jika sudah menjadi murid di organisasi tersebut. Kedua substansi tersebut dibangun berdasarkan pemahaman relasional pembudayaan bahwa wirid harus inheren dalam praktik kehidupan yang berpusat pada substansi teoritik tersebut. Berdasarkan pembudayaan struktur ajaran tersebut, organisasi ini bukan berperan sebagai organisasi keagamaan, akan tetapi merupakan organisasi budaya yang bertujuan untuk menanamkan nilai-nilai sakral melalui pembiasaan wirid dan adat istiadat baik dalam kehidupan murid.
\end{abstract}

Kata Kunci: konstruksi, ajaran budaya, Perguruan Ilmu Sejati

\begin{abstract}
This study is a content analysis study with a qualitative approach. The purpose of this study was to describe the construction of the cultural teachings of true knowledge seeker of trust in relation to Islamic values. The data collection is done with the study of documents and interviews to obtain confirmation of the teachings of text transcripts which are both analyzed by content analysis method. The analysis showed that the theoretical substance of cultural doctrine of Perguruan Ilmu Sejati is about morals or good customs that the term is a translation of the teachings of Sufism /
\end{abstract}


Morals in Islam according to individual knowledge Teachers who first started teaching wird. The substance of these cultural practices are wird teachings that can not be known unless it is already a student at the organization. Both substances are built on relational understanding of acculturation that wird should be inherent in the practice of life centered on the theoretical substance. Based on the teachings of the civilizing structure, this organization is not acting as a religious organization, but is the cultural organization that aims to instill the values of the sacred through habituation wirid and customs in both the student's life.

Keywords: contruction, cultural doctrine, Perguruan Ilmu Sejati

\section{A. Pendahuluan}

Prinsip-prinsip Penghayat Kepercayaan Ilmu Sejati merupakan konsep yang berakar pada falsafah sebagai berikut: Sahadat Kalimat Kalih (sahadat dua kalimat), zikir untuk memperkuat pokok keimanan, dan menjalankan adat istiadat baik seperti penjelasan "penget" (pengingat) bagi para anggota penghayat tersebut. Dalam sejarahnya pembentukannya, aliran penghayat ini merepresentasikan suatu pemahaman keislaman individu yang kemudian diminta oleh individu lain dan beberapa elemen masyarakat dengan latar belakang agama yang berbeda-beda untuk menjadikannya sebagai pembimbing keagamaan. ${ }^{1}$

Secara lahiriyah, meskipun merupakan pekumpulan yang bersifat budaya, ajaran-ajaran yang disampaikan perguruan tersebut tidak sedikit mengandung nilai-nilai moral Islam. ${ }^{2}$ Bahkan dikatakan bahwa ada tujuan yang sama antara Perguruan Ilmu Sejati dengan

${ }^{1}$ Perguruan Ilmu Sejati, Riwayat dan Perkembangan Perguruan Ilmu Sejati Sukorejo, Saradan, Madiun (Madiun: Perguruan Ilmu Sejati., 2014), h. 1-3

${ }^{2}$ Dalam kontek ini, keberadaan Perguruan Ilmu Sejati memiliki kesamaan dengan organisasi PSHT yang bertujuan membentuk manusia yang berbudi pekerti luhur. Hanya saja, jika dalam Perguruan Ilmu Sejati sumber keislamannya nampak dengan jelas sebagaimana dalam ajaran Syahadat Kalimat Kalih dan Dzikirnya, ajaran budi pekerti dalam PSHT yang secara historis juga bersumber dari ajaran Islam (tasawwuf) telah bercampur dengan budaya Jawa (akulturasi) yang pada gilirannya terwujud dalam bentuk simbolisme, sebagaimana tampak pada ritual "Pengesahan Warga Baru" PSHT ini. Lihat Fauzan, "Akulturasi Islam dan Budaya Jawa: Kajian pada Ritual "Pengesahan" Warga Baru Persaudaraan Setia Hati Terate" dalam KALAM, Volume VI, Nomer 1, Juni 2012, h. 105-124. 
berbagai agama, yaitu menuju kesucian, ${ }^{3}$ meskipun perspektifnya berbeda: yang pertama berperspektif budaya dan yang kedua berperspektif agama. Dua perspektif berbeda ini bertemu pada konteks lahiriyah yang merupakan budaya itu sendiri. Perbedaan perspektif ini memberikan suatu konsekuensi tentang perlunya konstruksi atau kajian ajaran Budaya Perguruan Ilmu Sejati dalam konteks moralitas dan nilai-nilainya yang secara asumtif memiliki dimensi kebudayaan Islam yang tampak dari tiga prinsip/falsafah ajarannya. Dalam konteks sosiologi, terindikasi bahwa nilai-nilai yang diajarkan perguruan ini merupakan nilai-nilai sakral yang teridentifikasi dari tujuannya yaitu menuju kesucian (kesakralan) ${ }^{4}$. Alasan ini merupakan hal yang menarik, di samping untuk tujuan konstruksi konsep ajaran, juga karena telah dicontohkan oleh Durkheim. ${ }^{5}$ Terkait dengan pemilihan struktur makna keislaman sebagai pembanding, hal ini dilatarbelakangi oleh tiga falsafah di atas yang dominan merepresentasikan nilai-nilai keislaman.

Secara teoritik, pemikiran tentang agama dalam konteks sosiologi dapat merupakan kajian yang berawal dari agama (termasuk di dalamnya adalah animisme). Durkheim dan Eliade menyebutnya dengan yang "sakral", yaitu kesucian relijius atau keramat. Meskipun kedua tokoh tersebut berbeda tentang karakteristik sakral, akan tetapi ada kesamaan makna yang menyatukan keduanya: yaitu yang memiliki arti relijius bagi umatnya baik dengan motivasi sosiologis Durkheim maupun dengan motivasi supernatural Eliade. ${ }^{6}$ Berbeda dengan keduanya, ada satu paradoks bahwa agama yang dikarakteristikkan dengan istilah-istilah tersebut justru dilihat dalam perspektif ekonomi semisal tema kapitalisme, khususnya Weber dan Marx. ${ }^{7}$ Pada Weber, istilah asketisme dan mistisisme sebagai representasi sakralitas tampak sekali dimasukkannya dalam perspektif

\footnotetext{
${ }^{3}$ Prawirosoedarso, Penget (Madiun: Perguruan Ilmu Sejati, 1931), h. 1-2

${ }^{4}$ Ibid.

${ }^{5}$ Daniel L. Pals, Seven Theories Of Religion, trans. oleh Ali Noer Zaman (Yogyakarta: Qalam, 2001).

${ }^{6}$ Pals, Seven Theories Of Religion, h. 158-160, 275-288

${ }^{7}$ B. S. Turner, Menggugat Sosiologi Sekuler, Analisis atas Sosiologi Weber, trans. oleh Abdullah Mudhofir (Suluh Press: Yogyakarta, 2005), h. 284-285; lihat pula: B. R. Scharf, Kajian Sosiologi Agama (Yogyakarta: Tiara Wacana, 1995), h. $178-181$
} 
tersebut dalam apa yang ia sebut sebagai "kabur dari dunia" ${ }^{8} \mathrm{Hal}$ ini bukan membantah logika yang bersangkutan, akan tetapi konteks keagamaan seharusnya dilihat dalam perspektif pengetahuan agama itu sendiri, yaitu menstrukturkan atau mengkonstruksikan secara logis makna-makna yang ada dalam agama sedemikian rupa sehingga konteks keaagamaan dilihat dalam konteks keagamaan itu sendiri, yaitu menginferensikan makna yang ada kepada konteks keagamaan yang relevan. Hal seperti ini merupakan konsep yang secara ketat dipegang oleh Durkheim melalui pusat pemikirannya, yaitu masyarakat sebagai yang sakral. ${ }^{9}$

Oleh karena itu, dalam konteks kajian teks dan transkrip wawancara dalam perspektif kajian teks, akan lebih tepat jika konstruksi demikian menggunakan analisis isi yang teorinya bersumber dari agama atau budaya dalam agama itu sendiri. Dalam konteks yang lebih luas, teks ajaran yang telah diproduksi oleh Perguruan perlu dikonfirmasikan dengan pemahaman yang mengiringinya. Maksudnya, karena teks yang dimaksudkan terkait dengan soal budaya dan praktek kebudayaan maka ia perlu direlasikan dengan teks hasil pembacaan.

Dalam konteks isi ajaran, telah disebutkan bahwa, secara prinsip, ajaran Perguruan Ilmu Sejati dominan merepresentasikan budaya keislaman, sehingga konsep pembandingnya adalah konsep dasar yang berlaku dalam agama atau budaya Islam. Dikatakan pula bahwa dalam penjelasan ajarannya, perguruan tersebut juga menerima murid non muslim, dengan catatan bahwa yang bersangkutan harus mengamalkan ajaran agama yang dianutnya. Hal ini bermakna bahwa konsep syahadat perguruan tersebut dapat diadaptasikan sesuai ajaran agama yang bersangkutan. Selanjutnya pada bagian "penget" atau konsep ajaran budaya sebagai pengingat murid perguruan tersebut, lebih banyak dijelaskan ajaran-ajaran moral yang mengandung unsur keislaman, di samping dua prinsip lainnya yang telah dijelaskan sebelumnya. Maksudnya, struktur ajaran tersebut lebih didominasi unsur-unsur moral keislaman yang digabung dengan konsep konsep pemahaman guru pertama di perguruan tersebut. Artinya, perguruan

\footnotetext{
${ }^{8}$ Max Weber, Sosiologi, trans. oleh Noorkholis dan Promothea (Yogyakarta: Pustaka Pelajar, 2006), h. 401

${ }^{9}$ Pals, Seven Theories of Religion, h. 166
} 
tersebut lebih terfokus pada soal moral atau ajaran budi pekerti yang di dalamnya ada petunjuk dan praktek inklusif tentang wirid. Dengan demikian, dapat dirumuskan bahwa sebagai organisasi budaya penghayat kepercayaan, Perguruan Ilmu Sejati merepresentasikan suatu pemahaman budaya keislaman yang terfokus pada soal moral yang digabung dengan konsep pemahaman guru di perguruan tersebut dengan patokan pemahaman dari guru pertama.

Terkait soal konsep keislaman, berikut ini adalah tiga prinsip keislaman yang merupakan rujukan umum di kalangan Muslim: pertama adalah Iman, yaitu mempercayai rukun iman yang enam, tema ini dapat dimasukkan dalam dimensi Akidah; kedua adalah Islam, yaitu menjalankan rukun Islam yang lima, tema ini dapat dimasukkan dalam dimensi syariat; ketiga adalah ihsan, yaitu beribadah kepada Allah seakan-akan melihatNya atau jika tidak, maka seakan-akan dilihat oleh-Nya, hal ketiga ini dapat dikategorikan dalam dimensi Akhlak/Tasawuf. Tiga konsep tersebut didasarkan pada hadis yang terdapat di berbagai kitab hadis populer. ${ }^{10}$ Namun demikian, penjelasan terkait hadis tersebut tidak dipahami secara sama oleh kelompok atau aliran dalam Islam. ${ }^{11} \mathrm{Hal}$ ini tidak begitu berarti, karena tujuan dari penjelasan teoritik di sini adalah untuk menjelaskan bahwa struktur pokok dari Islam yang terdiri dari tiga konsep tersebut adalah kuat dan terkait dengan soal pokok ibadah

${ }^{10}$ Sulaimān ibn al-Asy'aṡ ibn Ishāā al-Sijistān̄̄ Abū Dāwud, Sunan Abī Dāwud, ed. oleh Muhammad Muhy al -Dîn ÁAbd Al -Ḥamîd, vol. IV (Beirut: AlMaktabah al-Miṣriyyah, 2009)., h. 81. Abū Abd Allāh Muhammad ibn Yazīd alQuzwain Ibn Mājah, Sunan Ibn Mājah (Mesir: Dār Ihyā' al-Kutub, n.d.), h. 24. Muḥammad ibn Ismā'̄il Al-Bukhārī, Șahīh al-Bukhārī, ed. oleh M. Zuhair, vol. I (Dar Thauq al-Najah, 1422), h. 19.Muslim ibn al-Hajjāj Abū al-Ḥasan al-Qusyairī Al-Naisābūrī, Șah̄̄h Muslim, vol. I (Beirut: Dār al-Ihyā' al-Turaś al-'Arabī, n.d.), h. 36. Muhammad ibn Hibban ibn Ahmad ibn Hiban, Al-Ihsan fi Taqrib Shahih Ibnu Hiban, ed. oleh S. Al-Arna'uth (Beirut: Muassasah Al-Risalah, 1988), h. 375.Abū Abd al-Raḥmān Aḥmad ibn Syu'aib ibn Al̄̄ al-Khurasānī al-Nasā'̄̄, al-Sunan alSugrā lī al-Nasā '̄o, vol. VIII (Halb: Maktabah al-Matbu'āt al-Islāmiyyah., 1986), h. 97.Abū 'Abd Allāh Aḥmad ibn Muhammad ibn Muḥammad ibn Hanbal, Sunan alImām Ahmad ibn Hanbal, ed. oleh Aḥmad Syākir, vol.I (Kairo: Dar al-Hadīì, 1995), h. 243.Abū Bakr al-Naisābūrī Muhammad ibn Khuzaimah, Ṣaḥ̄h Ibn Khuzaimah, ed. oleh M. M. al-A'dzami, vol. I (Beirut: al-Maktab al-Islāmī, n.d.), h. 5.

${ }^{11}$ Syihab al-Din Abu al-Fadhl Ahmad ibn Ali ibn Muhammad ibn Muhammad ibn Ali ibn Mahmud ibn Ahmad ibn Hajar al-'Asqalānī, Fath sl-Bāri Syarh Shahihhal-Bukhāri, vol. XIII (Beirut: Dar al-Ma'rifah, 1379), h. 425. 
secara keseluruhan ${ }^{12}$ (As-Suyuthi, 1996: 8), sedangkan perbedaan yang terkait tema struktur pokok tersebut tidak sama antara satu dengan yang lain. Hal ini juga tidak menjadi masalah, karena tiga istilah sebagai patokan pemahaman Islam tersebut secara umum dijadikan sebagai patokan makna bukan dimaksudkan sebagai parameter untuk menilai ajaran budaya perguruan tersebut. Artinya, untuk membantu menguraikan adanya akar Sufistik atau Akhlak Islam sebagai dasar pengetahuan budaya Ilmu Sejati misalnya, akan lebih tepat jika didahului dengan konseptualisasi makna pokok nilai keislaman yang diperbandingkan.

Sebagai konsekuensinya, karena kerangka makna keislaman tersebut hanya sebagai parameter makna secara umum, meskipun dapat menjadi sumber pengetahuan Ilmu Sejati, maka kerangka untuk konstruksi ajaran perguruan ilmu sejati akan lebih difokuskan pada tipologi yang dibuat perguruan tersebut. Sedangkan untuk melihat relasinya, tipologi umum tentang nilai keislaman di atas merupakan acuan bagi kesamaan-kesamaan makna budaya dari sisi struktur luarnya. Unsur terdalam dari isi ajaran budaya perguruan, sebagaimana penjelasan sebelumnya, adalah dari perguruan yang bersangkutan. Bagaimana karakteristik atau konstruksi ajaran tersebut dari segi struktur logisnya, adalah yang dikaji dalam kajian analisis isi ini, yaitu menginferensikan makna ajaran pada konteks logis strukturnya sedemikian rupa sehingga secara struktur akan ditemukan bagian pusatnya sebagai hasil relasi makna-makna ajaran budaya Perguruan Ilmu Sejati yang terindikasi berelasi dengan nilai-nilai keislaman. Secara disiplin, kajian ini juga tidak terkait dengan persoalan antropologis tanggapan murid atau anggota masyarakat yang keluar dari prinsip umum yang masih dipegang, misalnya tentang pergeseran nilai dari perspektif penyerahan diri ke persoalan duniawi ${ }^{13}$ atau semacamnya, akan tetapi lebih ke persoalan konstruksi sebagaimana telah dijelaskan.

${ }^{12}$ 'Abd al-Raḥmān ibn al-Kamāl Abī Bakr Sābiq al-Dīn Jalāl al-Dīn AlSuyuṭ̂i, al-Dībāj 'ala Ṣahīh Muslim bin Al-Hajjājo, vol.I (Saudi Arabia: Dar Ibn 'Affan, 1996), h. 8.

${ }^{13}$ N. Mulder, Di Jawa, Petualangan Seorang Antropolog, trans. oleh Sofia Mansoor (Yogyakarta: Kanisius, 2007), h. 224 
Secara kepustakaan, kajian terhadap perguruan tersebut telah dilakukan sebelumnya. Berdasarkan kajian pustaka Ida Purwanti, khususnya pada karya Hernawati berjudul "Tradisi Kebatinan pada Perguruan Ilmu Sejati Desa Sukorejo Kecamatan Saradan Kabupaten Madiun", belum ada penelitian sebelumnya yang mengkaji tentang konstruksi ajaran kebatinan dalam membangun karakter masyarakat yang dikaji olehnya. ${ }^{14}$ Dalam kajian tersebut juga belum ada kajian konstruksi substansi ajaran dalam konteks sakralitasnya.

Hasil penelitian terdahulu terkait penelitian terhadap Penghayat Kepercayaan atau Kebatinan Perguruan Ilmu Sejati menunjukkan bahwa pertama, perguruan tersebut telah menunjukkan kepatuhannya terhadap peraturan pemerintah dan perundangan-undangan yang berlaku di Indonesia dan bahwa ajaran moral Perguruan Ilmu Sejati mampu membangun sikap moral dan jiwa Pancasila. ${ }^{15}$

Berdasarkan beberapa penjelasan tersebut dapat dipahami adanya relasi makna sakralitas antara makna keislaman dan makna tradisi atau antara struktur makna keduanya. Selain itu, ada dominasi unsur-unsur kesamaan antara ajaran budaya perguruan tersebut dengan nilai-nilai moral keislaman. Terkait dengan hal itu, tulisan ini berupaya menganalisis secara kualitatif bagaimana konstruksi sakralitas dan ajaran budaya penghayat kepercayaan ilmu sejati dalam relasinya dengan nilai keislaman. Dalam hal ini data-data digali dari kelompok penghayat kepercayaan Ilmu Sejati terkait konsep ajarannya dan mengkonfirmasikan antara teks acuan yang dikaji dengan teks hasil wawancara. Data-data tersebut kemudian dideskripsikan secara mendalam untuk mengkonstruksi struktur pusat ajarannya dan relasinya dengan struktur yang ada di bawahnya.

Dengan menggunakan paradigma kritis, kajian ini menempatkan konsep-konsep ajaran pada konteksnya untuk menentukan pusat struktur ajaran sebagai penentu relasi makna ajaran setelah merelasikannya dengan konsep ajaran moral lain yang

\footnotetext{
${ }^{14}$ Ida Purwanti, "Sejarah, Konstruksi dan Sosialisasi Ajaran Perguruan Ilmu Sejati” (Skripsi, Universitas Negeri Malang, 2012)., h. 1-4.

${ }^{15}$ Ida Purwanti, "Sejarah, Konstruksi dan Sosialisasi Ajaran Perguruan 'Ilmu Sejati' (Studi pada Perguruan 'Ilmu Sejati' di Desa Ketanon, Kecamatan Kedungwaru, Kabupaten Tulungagung).”(Skripsi, Universitas Negeri Malang, 2012), http://karya-ilmiah.um.ac.id/index.php/sejarah/article/view/23090, h. 1-4.
} 
terdekat, yaitu karakteristik nilai keislaman sebagai sumber ajaran. Oleh karena itu, dalam tahapan analisis, karakteristik-karakteristik relasi keduanya dipahami sebagai struktur makna yang saling terkait satu sama lain sebagai sistem makna.

\section{B. Profil Perguruan Ilmu Sejati}

\section{Sejarah Singkat}

Hasil wawancara dengan wakil guru Perguruan Ilmu Sejati yang didukung dokumen profilnya menunjukkan bahwa perguruan tersebut didirikan bukan atas inisiatif guru pertama perguruan tersebut. Dijelaskan bahwa pada awalnya Perguruan Ilmu Sejati tidak dapat dilepaskan dari pemimpin pertamanya bernama (Raden) Soedjono Prawiro Soedarso, putra dari (Raden) Ngabei Kertokusumo, yang dilairkan pada tahun 1875 di Sumberumis Madiun. Ia merupakan keturunan ke 17 dari Prabu Brawijaya, Raja Majapahit yang terakhir, ke-13 dari Ki Ageng Pamanahan Mataram, ke 11 dari Kanjeng Sinuwun Anyokrowati Mataram, ke 9 dari Raja Bima, dan ke-6 dari Kanjeng Pangeran Mangkunegoro Madiun. ${ }^{16}$

Diceritakan bahwa pada Tahun 1883 ia menimba ilmu dari KH. Samsudin Betet, Padangan, Bojonegoro, dan mendapatkan ilmu terkait ajarannya dari Imam Sufingi. Selanjutnya pada tahun 1893 ia telah menamatkan sekolahnya. Pada Tahun 1896, ia bekerja di Kantor Karesidenan Yogyakarta sampai dengan tahun 1905 dimana ia memutuskan berhenti dari pekerjaannya dan melanjutkan perjalanan untuk kembali berguru. Tidak kurang dari 52 perguruan yang didatangi. Dalam perjalanan bergurunya ia mendapatkan pengalaman sakral berupa pertemuannya dengan para wali.Selanjutnya, pada tahun 1910, ia menjadi anggota Syarikat Islam Jepara sambil bertani di lereng Gunung Muria, akan tetapi pada Tahun 1920 ia keluar dari perkumpulan tersebut karena terpecah menjadi dua kubu. Secara organisasi, perguruan tersebut didirikan pada 13 Oktober 1925, bertepatan dengan tanggal surat tanda penerimaan no. 2 tanggal 13

${ }^{16}$ Sejati, Riwayat dan Perkembangan Perguruan Ilmu Sejati Sukorejo, Saradan, Madiun, h. 1-2.Bambang W. Djati, Sejarah dan Perkembangan Perguruan Ilmu Sejati, Nurul Huda, 28 November 2016. 
Oktober 1925, menurut Guru Ordonansi 1925 Staatblat 1925, No. 219 artikel $1 .^{17}$

Perkembangan selanjutnya, pada tahun 1961, Soedjono Prawirosoedarso wafat, akan tetapi putra kandungnya Soewarno Prawirosoedarso yang ditunjuk sebagai pengganti masih menempuh pendidikan Secapa Wamil Zeni AD di Bogor. Kepengurusan selanjutnya dipegang oleh Soehardjo, mantan Anggota DPR RI pertama, dan kemudian oleh Djoko Soewarso, perwira menengah TNI AD, putra menantu Soedjono Prawirosoedarso, sampai dengan tahun 1999. Selanjutnya perguruan tersebut digantikan kepengurusannya oleh Soewarno Prawirosoedarso sampai dengan Tahun 2010. Setelah itu dan sampai saat ini, kepengurusan perguruan tersebut dipimpin oleh Kresno Dwipoyono, SE, yang dikukuhkan pada 12 Oktober 2011 dengan sebutan Romo R Kresno D. Prawirosoedarso, SE. Sampai dengan 16 Mei 2014, murid Perguruan berjumlah 5.672.296 yang tersebar di seluruh Indonesia, dengan wakil murid berjumlah 7.408 orang. ${ }^{18}$ Menurut Ismono, selaku pejabat terkait dari Kantor Pendidikan Nasional Kabupaten Madiun, Perguruan Ilmu sejati berada di bawah pembinaan lembaganya, dan perguruan tersebut termasuk penghayat kepercayaan yang berada dalam wilayah pembinaan Diknas. Hal ini juga dibenarkan oleh wakil guru perguruan tersebut ${ }^{19}$.

\section{Pandangan Perguruan Ilmu Sejati Sebagai Penghayat Kepercayaan di Indonesia}

Menurut Ismono, selaku pejabat terkait dari Kantor Pendidikan Nasional Kabupaten Madiun, Perguruan Ilmu sejati berada di bawah pembinaan lembaganya, dan perguruan tersebut termasuk penghayat kepercayaan yang berada dalam wilayah pembinaan Diknas. ${ }^{20} \mathrm{Hal}$ ini juga dibenarkan oleh wakil guru perguruan tersebut. Dikatakan bahwa sebagai penghayat yang termasuk dalam pembinaan Diknas Perguruan Ilmu Sejati termasuk organisasi budaya, bukan termasuk

${ }^{17}$ Sejati, Riwayat dan Perkembangan Perguruan Ilmu Sejati Sukorejo, Saradan, Madiun., h. 1-5

${ }^{18}$ Ibid., h. 5-12.

${ }^{19}$ Djati, Sejarah dan Perkembangan Perguruan Ilmu Sejati.

${ }^{20}$ Ismono, Beberapa Hal tentang Perguruan Ilmu Sejati, Nurul Huda, 2 Desember 2016. 
agama tertentu dan bukan merupakan agama baru, dan tidak akan mendirikan agama baru. ${ }^{21}$

\section{Sumber Ajaran Budaya Ilmu Sejati}

Ajaran perguruan ilmu sejati merupakan ajaran yang bersumber dari ajaran budaya yang diajarkan oleh guru pertama perguruan tersebut. Hal ini dinyatakan dalam dokumen Perguruan sebagai berikut: "ajaran Perguruan Ilmu Sejati sampai sekarang tetap konsisten tetap bersumberkan wulang 'ajaran budaya' dari Romo R. Soedjono Prawirosoedarso". Pada bagian lain, perguruan tersebut disebutkan dengan "hasil karya ilmu" yang digali oleh guru pertama tersebut. $^{22}$

\section{Pandangan terhadap Keyakinan Agama}

Menurut Bambang Wahjoe Djati, salah satu wakil guru perguruan tersebut, perguruan ilmu sejati merupakan organisasi budaya dan termasuk dalam kategori penghayat kepercayaan yang anggotanya terdiri dari para penganut agama di Indonesia, yaitu Islam, Kristen, Hindu dan Budha. Organisasi ini menghendaki agar para penganut agama tersebut dapat menjalankan agamanya masingmasing dengan baik. ${ }^{23}$

\section{Bentuk Pengamalan Pokok Keyakinan dalam Kepercayaan Perguruan Ilmu Sejati}

Ajaran budaya perguruan ilmu sejati mengajarkan 3 hal pokok, yaitu: 1) Dua kalimat syahadat; 2) Zikir tarek untuk mengembangkan pokok keimanan; dan 3) Surat penget yang berisi pelajaran adat istiadat baik. ${ }^{24}$ Khusus nomor dua, pihak perguruan melalui wakil guru tidak bersedia menjelaskan. ${ }^{25}$ Penjelasan terkait wirid dalam dokumen Perguruan dan kaitannya dengan pengamalannya disebutkan sebagai berikut:

${ }^{21}$ Bambang W. Djati, Konsep Ajaran Perguruan Ilmu Sejati dan Responnya atas Konteks Sosial Terkait, Nurul Huda, 28 November 2016.

${ }^{22}$ Perguruan Ilmu Sejati, Ensiklopedi Perguruan Ilmu Sejati (Madiun: Perguruan Ilmu Sejati, 2016), h. 1-4.

\footnotetext{
Sosial Terkait.

${ }^{24}$ Prawirosoedarso, Penget, h. 4.

${ }^{25}$ Djati, Konsep Ajaran Perguruan Ilmu Sejati dan Responnya atas Konteks Sosial Terkait.
}

${ }^{23}$ Djati, Konsep Ajaran Perguruan Ilmu Sejati dan Responnya atas Konteks 
"Kegiatan Perguruan Ilmu Sejati melalui wirid, tanpa sarana, dapat dilakukan sewaktu-waktu, di Pemulangan Perguruan Ilmu Sejati dan atau di rumah wakil mirid/mulang di daerah masingmasing dan tidak di tempat umum.

Selanjutnya pengamalannya dalam tata kehidupan adalah pembinaan budi pekerti luhur, kasih sayang dengan sesama yang hidup tuntunan prilaku murid berpegang pada surat penget sebagai pegangan seluruh murid Ilmu Sejati yang telah dipegang sendiri-sendiri”. ${ }^{26}$

Lebih jelas lagi, berikut adalah ajaran budaya yang digali berdasarkan studi dokumen "Penget" karya guru pertama Perguruan (terjemahan):

a. Wajib mengetahui masuknya keimanan dalam tiga lafal berikut: LHAILA-HAILOLLAH (3X), ILLOLAH (3X), ALLAH (3X).

b. Menepati/melaksanakan 5 (lima) rukun Islam: 1) Syahadat, 2) Salat, 3) Zakat, 4) Puasa, 5) Haji.

c. Menjalankan 5 tata krama terhadap: 1) bapak dan ibu kandung, 2) bapak dan ibu mertua, 3) saudara ayah dan ibu kandung, 4) ratu, yaitu pemerintah Republik Indonesia, 5) guru, yang membimbing ke arah pencerahan hati.

d. Menjalankan sikap-sikap sebagai berikut:1) sabar, 2) tawakal, 3) rela, 4) menerima, dan 5) rajin.

e. Kasih sayang terhadap sesama makhluk hidup.

f. Selain itu, perlu menjauhi prilaku buruk, seperti: 1) iri hati, 2) egois, 3) memfitnah, 4) aniaya, dan lain-lain.

g. Menjauhi 5 bab maksiat: 1) narkoba (madad), 2) zina (madon), 3) minuman keras (minum), 4) mencuri (maling), 5) judi (main).

h. Mencegah atau menyingkirkan perbuatan yang menjunjung dan menurut terhadap pembicaraan takhayul orang lain, yaitu menyekutukan Allah. Maksudnya meremehkan terhadap kekuasaan Tuhan.

i. Menjalankan semampunya hal-hal berikut ini:

\footnotetext{
${ }^{26}$ Prawirosoedarso, Penget, h. 4 ..
} 
1) Tapa raga (melatih raga agar terhindar dari persoalan /maksiat ragawi) meliputi 7 (tujuh) bab: a). Tidak tidur (tapa mata) agar tidak melihat karena niat tidak baik; b). Menghindari nafsu (tapa kuping) agar tidak mendengar- kan gunjingan/keburukan orang lain; c). Menghindari minum (tapa hidung) agar tidak menghisap keburukan orang; d). Menghindari makan (tapa mulut) agar tidak menggunjing/ menceritakan keburukan orang lain; e). Menghindari mengambil milik orang lain (tapa tangan); f). menghindari sahwat (tapa kemaluan) agar tidak berbuat zina; g). menghindari berjalan untuk perbuatan jahat (tapa kaki) agar senang berjalan untuk kebaikan.

2) Tapa jiwa (melatih jiwa agar terhindar dari persoalan/ maksiat kejiwaan) meliputi 7 (tujuh) bab: a) rendah hati agar menyukai perbuatan baik; b) sifat menerima agar tidak memiliki keinginan buruk; c) rela agar sabar terhadap cobaan; d) rajin / tidak malas; e) tabah agar tahan terhadap hal yang membuat nelangsa; f) sifat utama agar hening/ tenang; g) waspada/hati-hati agar selalu ingat.

3) Ingat akan pengetahuan jika merasakan 5 hal: a) jika sakit badan maka harus menerima, rajin (berobat), dan rela; b) Jika badan terasa tidak enak maka harus betah dan berjalan dengan keluasan hati; c) Jika hati gelap maka harus diam, hening, awas/waspada dan ingat; d) Jika hati sakit maka perlu menata (hati), meneliti, memutuskan, berhati-hati; e) Jika hati dipenuhi ketertutupan maka perlu dimasuki dengan berani, mendesakkan (kebaikan), percaya dan dipercaya; f) Menjaga tekad ada dua bab, yaitu (1) Jangan berkurang fokus penglihatannya, jangan malu tertinggal orang lain, bisa mengurangi semangat dan (2) Jangan kecil hati; dan g). Tekanan hidup meliputi 2 bab, yaitu (1) Tekanan terhadap raga meliputi 5 macam berikut: (a) Prilaku ceroboh, (b) Melakukan hal nista, (c) Melakukan hal tidak terpuji, (d) Malas dan gampang malu, (e) Gampang bersedih; dan ( 2) Tekanan terhadap jiwa meliputi 5 macam: (a) Mengumbar hawa nafsu, (b) Mengumbar kesukaan, (d) Mengumbar kemarahan, (e) Mencederai (hati) orang lain, (f) Melakukan 
Fitnah, (g) Yang membantah/melawan tokoh agama, akan sengsara, (h) Yang membantah/melawan guru akan menemui kerusakan, (i) Siapa yang mengabaikan petuah orang tua yang benar-benar, akan mengalami hanyut sebelum tercebur air, (j) Jangan membeda-bedakan terhadap sesama, (k) Jangan membeda-bedakan terhadap bangsa lain, (l) Jangan mengolok-olok terhadap seluruh agama berikut seluruh pengetahuan serta tekad yang ada pada orang lain. ${ }^{27}$

Selain hal di atas, Perguruan Ilmu Sejati menggarisbawahi tentang penjelasan keorganisasiannya, yaitu:

a... Bukan organisasi politik... b. Secara batin bertujuan untuk menuju kepada Tuhan Yang Maha Esa dengan hati suci; c. Secara lahir ikut menegakkan Negara Kesatuan Republik Indonesia yang berdasarkan Pancasila dan Undang-undang Dasar 1945; d. Ilmu Sejati bukan agama, bukan agama baru dan tidak akan membentuk agama baru; e. Ilmu sejati bukan klenik dan bukan perdukunan; f. Semua murid Perguruan Ilmu Sejati diharapkan menjadi warga negara yang baik, taat kepada pemerintah, dan tidak melanggar peraturan perundangundangan yang berlaku; g. Ilmu Sejati Sukorejo Saradan Caruban Madiun, merupakan perguruan yang terbentuk dengan sendirinya, tidak dengan sengaja didirikan oleh Romo Guru atau murid-muridnya; h. Perguruan Ilmu Sejati yang muridmuridnya tersebar di seluruh wilayah Indonesia tetap satu tujuan, ingin membantu pemerintah dalam bidang pembangunan fisik dan mental, dengan ketulusan hati, dengan hasil-hasil pembangunan untuk pemerataan sosial bagi seluruh rakyat Indonesia dan terciptanya masyarakat yang mengedepankan: 1) Ketenteraman umum; 2) Kemandirian 3) Kebersamaan (gotong royong) 4) Kerukunan, agar segera terwujudnya masyarakat yang adil makmur berdasarkan Pancasila dan Undang-undang dasar 45, dengan prilaku budaya sendiri, bagi seluruh bangsa Indonesia. ${ }^{28}$

${ }^{27}$ Ibid., h. 1-2.

${ }^{28}$ Sejati, Riwayat dan Perkembangan Perguruan Ilmu Sejati Sukorejo, Saradan, Madiun, h. 11-12 


\section{Konstruksi Ajaran Budaya Ilmu Sejati}

\section{Adanya Ajaran Budaya Terkait Keimanan}

Budaya keimanan diajarkan melalui pengetahuan keimanan yang secara makna ada unsur kesamaan makna dengan keimanan Islam. Secara keseluruhan, ajaran budaya tentang keimanan ini memang tidak sama secara tekstual dengan budaya dalam ajaran Islam terkait keimanan secara umum. Misalnya tidak takhayul atau syirik merupakan ajaran pengetahuan guru pertama Perguruan, akan tetapi pengembangan pengetahuan atau ajaran budaya ini tidak terbatas pada umat beragama Islam, sehingga dalam kategori ini, dapat dikatakan bahwa pengetahuan pergeruan tersebut berasal dari Islam akan tetapi telah diadaptasikan dengan pemahaman inklusif yang menerima komunitas di luar Islam.

\section{Adanya Ajaran Budaya Terkait Keislaman}

Budaya ini terepresentasikan melaui ajaran 5 rukun islam. Melalui pengamalan ini maka bagi muslim perlu mengucapkan dua kalimat syahadat sebagai syarat keislaman. Maksudnya, berdasarkan pengetahuan guru pertama Perguruan Ilmu Sejati bahwa tujuan Ilmu Sejati adalah sama dengan Semua Agama, murid Ilmu Sejati yang beragama Islam hendaknya mengamalkan rukun Islam yang lima.

\section{Adanya ajaran budaya terkait Akhlak}

Budaya ini terepresentasikan melalui ajaran-ajaran yang ada kesamaan, kemiripan, secara dominan, meskipun tampak tidak secara menyeluruh dengan budaya atau akhlak yang diajarkan dalam Islam.Secara khusus, terkait akhlak tersebut, tampak bahwa ajaran tentang tasawuf mendominasi tema perguruan Ilmu sejati. Hal ini tampak dari bahwa substansi perguruan tersebut adalah wirid.

\section{Berpusat pada Pengetahuan dan Pengalaman Guru Pertama Perguruan Ilmu Sejati}

Guru pertama Ilmu Sejati merupakan anggota perkumpulan Muslim Syarikat Islam, ia juga memasuki dunia kepesantrenan. Namun demikian, ajaran yang diajarkannya bersifat budaya, hal ini karena yang diajarkan adalah pengetahuan guru tersebut berdasarkan pemahaman dan pengalaman sakral yang pernah dialaminya. Artinya, pengetahuan yang ia ajarkan merupakan hasil pengalaman sufistik atau pengalaman sakral yang kemudian membentuk masyarakat 
sakral yang sesuai dengan proses sakral yang pernah dialami oleh guru pertama tersebut.

\section{Secara teoritik berpusat pada Ajaran Budaya Akhlak/Adat Istiadat Baik Guru Pertama}

Secata lahiriyah, dimensi budaya Akhlak/Sufisme ini dapat diketahui dari ajaran-ajaran yang mengandung nilai Akhlak atau adat istiadat baik yang disampaikan dalam "penget". Namun demikian, tentu tidak seluruhnya dapat direlasikan dengan konsep sufisme dalam kajian khusus, akan tetapi dalam konteks bahwa ada penerimaan masyarakat Islam- di samping non Islam-terhadap ajaran budaya Ilmu Sejati yang menunjukkkan bahwa secara budaya isi yang diajarkan dianggap dapat memberikan bimbingan bagi sebagian kalangan masyarakat. ${ }^{29}$

\section{Memiliki murid yang berlatar belakang agama bervariasi}

Seperti telah disebutkan sebelumnya, murid ilmu sejati yang berjumlah 5 (lima) juta lebih dan tersebar di seluruh wilyah Indonesia memiliki latar belakang agama yang bervariasi, yaitu Islam, Kristen, Hindu dan Budha. ${ }^{30} \mathrm{Hal}$ ini semakin menegaskan bahwa perguruan ilmu sejati merupakan perguruan yang menegaskan diri sebagai bagian dari gerakan atau pendidikan budaya. Yaitu, meskipun memiliki latar belakang ajaran yang bersifat keislaman, perguruan ini menegaskan bahwa ia bukan agama, tetapi budaya.

\section{Diproyeksikan sebagai Ajaran atau Pendidikan Budaya Moral Sufistik}

Sebagai ajaran budaya yang ditegaskan hanya berpusat pada wirid, yaitu sebagai syarat atau kunci memasuki Ilmu Sejati, di mana dalam penjelasannya berisi anjuran berprilaku monoteistik atau tidak syirik dalam berprilaku, juga sabar, tawakal, dan moral sufistik lainnya, perguruan ilmu sejati dapat dikarakteristikkan sebagai gerakan budaya yang mendukung pendidikan budaya moral sufistik atau Akhlak secara praktis. Meskipun bukan sebagai kajian relasi khusus, hal ini dapat dilihat dari relasi umum adanya kesamaan istilah

\footnotetext{
${ }^{29}$ Iyah, Manfaat Wirid dan Ajaran Perguruan Ilmu Sejati, Nurul Huda, 25 November 2016.

${ }^{30}$ Djati, Konsep Ajaran Perguruan Ilmu Sejati dan Responnya atas Konteks Sosial Terkait.
} 
semacam sabar, tawakal, dan beberapa istilah akhlak lainnya yang ditemukan dalam pelajaran pengingat bagi murid Perguruan Ilmu Sejati.

\section{Berpusat pada Substansi Praktik Berupa Ajaran Tentang Wirid Yang Hanya Dapat Diketahui Oleh Kalangan Perguruan Ilmu Sejati.}

Berdararkan substansi praktik tersebut, meskipun hanya bagi kalangan sendiri, dapat diketahui bahwa substansi umum berupa wirid tersebut diaplikasikan melalui adat istiadat baik yang mendasarkan pada acuan tertulis berjudul "Penget" yang disusun oleh guru pertama perguruan tersebut.Namun demikian menurut Iyah, yang mewakili beberapa murid Perguruan Ilmu Sejati, wirid yang dipraktekkannya selama ini benar-benar dapat dirasakan manfaatnya dalam kehidupan sehari-hari. ${ }^{31}$

9. Terdapat unsur Ajaran Akhlak/Tasawuf atau dimensi ihsan -dalam Islam- yang terkait dengan pengalaman praktis atau pengetahuan praktis guru pertama Perguruan

Sebagaimana telah disebutkan, guru pertama Perguruan adalah seorang muslim yang pernah bergabung dalam organisasi Syarikat Islam setelah mengalami pengalaman sakral dalam "pengembaraan" ilmunya. Pengetahuan keagamaan yang didukung dengan pengalaman praktek keagamaan tersebut membentuk suatu pribadi yang berbeda di banding orang awam, terlihat dari banyaknya jumlah murid yang meminta wirid kepadanya. Deskripsi berdasarkan profil - yaitu masuk pendidikan pesantren, berguru ke para wali, dan lain-lain - dan data perkembangan Perguruan memberikan suatu pemahaman bahwa wirid yang diberikan kepada murid adalah wirid yang harus didukung dengan adat istiadat baik. Meski tidak tekstual secara keseluruhan, tampak bahwa adat istiadat baik yang diajarkan olehnya merupakan terjemahan dari ajaran-ajaran untuk memperbaiki kualitas ibadah (ihsan) yang termasuk dalam bidang Akhlak/Tasawuf.

10. Adanya dukungan terhadap Negara Kesatuan Republik Indonesia, Pancasila dan UUD 1945 dan terhadap pemerintah.

\footnotetext{
${ }^{31}$ Iyah, Manfaat Wirid dan Ajaran Perguruan Ilmu Sejati.
} 
Sebagaimana telah disebutkan, bahwa Perguruan Ilmu Sejati telah menegaskan untuk setia dan mendukung Pemerintah Negara Kesatuan Republik Indonesia (NKRI) yang berdasarkan Pancasila dan Undang-undang Dasar 1945.Hal ini juga tampak dari profil kesejarahannya yang secara konsisten menunjukkan keberpihakannya pada NKRI.

\section{Penutup}

Perguruan Ilmu Sejati merupakan organisasi penghayat kepercayaan yang dalam sejarahnya terbentuk secara bottom up yaitu berdasarkan permintaan individu dan masyarakat untuk dijadikan murid wirid dari guru pertama perguruan tersebut. Substansi teoritik ajaran budaya Perguruan Ilmu Sejati adalah ajaran moral atau adat istiadat baik yang secara istilah merupakan terjemahan dari ajaran Tasawuf/Akhlak dalam Islam berdasarkan pengetahuan individual Guru pertama Perguruan. Substansi Praktik ajarannya adalah wirid yang hanya bisa diketahui oleh para murid perguruan tersebut.

Secara teoritik dan praktik, totalitas struktur berdasarkan dua pusat struktur tersebut memberikan penegasan bahwa isi ajaran berikut wiridnya, tidak dapat dikategorikan sebagai agama dan hanya terkait dengan konteks Akhlak, jika dikaitkan dengan konteks Islam sebagai Agama yang berisi Iman, Islam, dan Ihsan. Dimasukkannya norma keislaman sebagai bagian ajaran budaya yang bepusat pada tema moral pada Perguruan Ilmu sejati memberikan makna bahwa fokus ajaran budaya perguruan tersebut terkait dengan nilai akhlak yang berpusat pada ajaran wirid. Dengan demikian, berdasarkan pandangan Perguruan Ilmu Sejati tentang kesamaan tujuannya dengan semua agama dalam konteks menuju kesucian, tampak bahwa perguruan tersebut menghendaki peran relijiusnya secara budaya bahwa ajaran budaya yang dikembangkannya dapat mendukung pengamalan ajaran agama yang diyakini masing-masing murid Perguruan. Relasi substansi praktik dan teoritik dibangun berdasarkan pemahaman pembudayaan bahwa wirid harus inheren dalam praktik kehidupan yang berpusat pada substansi teoritik tersebut.

Berdasarkan pembudayaan struktur ajaran tersebut, organisasi ini bukan berperan sebagai organisasi keagamaan, akan tetapi merupakan organisasi budaya yang bertujuan untuk menanamkan 
nilai-nilai sakral melalui pembiasaan wirid dan adat istiadat baik dalam kehidupan murid. Sebagai cross check simetris, tampak bahwa relasi antara nilai dalam ajaran Ilmu Sejati dengan nilai dalam ajaran Islam ada yang sama, ada yang berbeda.Kemudian secara budayayaitu praktik- juga ada yang sama dan ada yang berbeda. Artinya, persamaan dan perbedaan yang telah diuraikan dalam karakteristik ajaran budaya Ilmu sejati tidak dapat menegasikan adanya pilahan struktur yang benar-benar sama dan berbeda. Secara epistemologis, karena di balik ajaran tersebut berlaku nilai keislaman yang berpusat pada dimensi sakralitas ajaran Islam dalam perspektif kepesantrenandi samping sakralitas dari sisi budaya-maka tidak dapat dipungkiri bahwa dalam struktur pusat meta ajaran budaya Ilmu Sejati terdapat konsep moralitas keislaman sebagai perspektif. Tegasnya, relasi antara konsep sakralitas budaya dengan latar belakang pesantren yang juga meneguhkan konsep sakralitas menghasilkan sintesa dengan substansi yang sama; sedangkan relasi budaya antara praktik nilai ajaran Ilmu Sejati dengan praktik nilai ajaran Islamtidak bertemu dalam konsep sistemik yang sama. Hal ini karena pusat perspektif keduanya tidak sama, yang pertama adalah sebagai budaya-diperkuat dengan pengalaman pribadi pendiri-, yang kedua adalah budaya atau praktik sebagai bagian pelaksanaan sistem keyakinan ajaran Islam. [] 


\section{DAFTAR PUSTAKA}

Al-Asqalani, Syihab al-Din Abu al-Fadhl Ahmad ibn Ali ibn Muhammad ibn Muhammad ibn Ali ibn Mahmud ibn Ahmad ibn Hajar.Fath Al-Bari Syarh Shahih Al-Bukhari. Vol. XIII. Beirut: Dar al-Ma'rifah, 1379.

Al-Bukhārī, Muḥammad ibn Ismā’̄̄l. Șahīh al-Bukhārī.Diedit oleh M. Zuhair.Vol. I. Dar Thauq al-Najah, 1422.

Al-Naisābūrī, Muslim ibn al-Ḥajjāj Abū al-Ḥasan al-Qusyairī.Ṣah̄h Muslim.Vol. I. Beirut: Dār al-Ihyā' al-Turas al-' Arabī, n.d.

Al-Nasā'̄̄̄, Abū Abd al-Raḥmān Aḥmad ibn Syu'aib ibn Alī alKhurasānī.al-Sunan al-Sugrā lī al-Nasā'̄ō. Vol. VIII. Halb: Maktabah al-Matbu'āt al-Islāmiyyah., 1986.

Al-Suyuṭị, 'Abd al-Raḥmān ibn al-Kamāl Abī Bakr Sābiq al-Dīn Jalāl al-Dīn. al-Dībāj 'ala Șahīh Muslim bin Al-Hajjāj. Vol. I. Saudi Arabia: Dar Ibn 'Affan, 1996.

Dāwud, Sulaimān ibn al-Asy'aś ibn Isḥāq al-Sijistānī Abū.Sunan Ab̄̄ Dāwud. Diedit oleh Muḥammad Muhy al -Dîn Adbd Al Hamîd.Vol. IV. Beirut: Al-Maktabah al-Mișriyyah, 2009.

Djati, Bambang W. Konsep Ajaran Perguruan Ilmu Sejati dan Responnya atas Konteks Sosial Terkait. Nurul Huda, 28 November 2016.

. Sejarah dan Perkembangan Perguruan Ilmu Sejati. Nurul Huda, 28 November 2016.

Fauzan, "Akulturasi Islam dan Budaya Jawa: Kajian pada Ritual "Pengesahan" Warga Baru Persaudaraan Setia Hati Terate" dalam KALAM, Volume VI, Nomer 1, Juni 2012, h. 105-124

Ḥanbal, Abū 'Abd Allāh Aḥmad ibn Muhammad ibn Muhammad ibn.Sunan al-Imām Ahmad ibn Hanbal.Diedit oleh Ahmad Syākir. Vol. I. Kairo: Dar al-Hadīì, 1995.

Hiban, Muhammad ibn Hibban ibn Ahmad ibn.Al-Ihsan fi Taqrib Shahih Ibnu Hiban.Diedit oleh S. Al-Arna'uth. Beirut: Muassasah Al-Risalah, 1988.

Ismono.Beberapa Hal tentang Perguruan Ilmu Sejati.Nurul Huda, Desember 2016.

Iyah.Manfaat Wirid dan Ajaran Perguruan Ilmu Sejati. Nurul Huda, 25 November 2016. 
Khuzaimah, Abū Bakr al-Naisābūrī Muḥammad ibn.Ṣaḥịh Ibn Khuzaimah.Diedit oleh M. M. al-A'dzami. Vol. I. Beirut: alMaktab al-Islāmī, n.d.

Mājah, Abū Abd Allāh Muhạmmad ibn Yazīd al-Quzwain Ibn.Sunan Ibn Mājah. Mesir: Dār Ihyā' al-Kutub, n.d.

Mulder, N. Di Jawa, Petualangan Seorang Antropolog. Diterjemahkan oleh Sofia Mansoor. Yogyakarta: Kanisius, 2007.

Pals, Daniel L. Seven Theories Of Religion. Diterjemahkan oleh Ali Noer Zaman. Yogyakarta: Qalam, 2001.

Prawirosoedarso, Penget, Madiun: Perguruan Ilmu Sejati, 1931.

Purwanti, Ida. "Sejarah, Konstruksi dan Sosialisasi Ajaran Perguruan Ilmu Sejati." Skripsi, Universitas Negeri Malang, 2012.

, "Sejarah, Konstruksi dan Sosialisasi Ajaran Perguruan 'Ilmu Sejati' (Studi pada Perguruan 'Ilmu Sejati' di Desa Ketanon, Kecamatan Kedungwaru, Kabupaten Tulungagung).” Skripsi, Universitas Negeri Malang, 2012. http://karyailmiah.um.ac.id/index.php/sejarah/article/view/23090.

Scharf, B. R. Kajian Sosiologi Agama. Yogyakarta: Tiara Wacana, 1995.

Sejati, Perguruan Ilmu. Ensiklopedi Perguruan Ilmu Sejati. Madiun: Perguruan Ilmu Sejati, 2016.

. Riwayat dan Perkembangan Perguruan Ilmu Sejati Sukorejo, Saradan, Madiun. Madiun: Perguruan Ilmu Sejati., 2014.

Turner, B. S. Menggugat Sosiologi Sekuler, Analisis atas Sosiologi Weber. Diterjemahkan oleh Abdullah Mudhofir. Suluh Press: Yogyakarta, 2005.

Weber, Max. Sosiologi.Diterjemahkan oleh Noorkholis dan Tim Penerjemah Promothea. Yogyakarta: Pustaka Pelajar, 2006. 